\title{
Influence of nanophase titania topography on bacterial attachment and metabolism
}

\author{
Margaret R Park' \\ Michelle K Banks' \\ Bruce Applegate ${ }^{2}$ \\ Thomas J Webster ${ }^{3}$ \\ 'School of Civil Engineering; \\ ${ }^{2}$ Department of Food Science; ${ }^{3}$ School \\ of Biomedical Engineering, Purdue \\ University, West Lafayette, IN, USA
}

\begin{abstract}
Surfaces with nanophase compared to conventional (or nanometer smooth) topographies are known to have different properties of area, charge, and reactivity. Previously published research indicates that the attachment of certain bacteria (such as Pseudomonas fluorescens 5RL) is higher on surfaces with nanophase compared to conventional topographies, however, their effect on bacterial metabolism is unclear. Results presented here show that the adhesion of Pseudomonas fluorescens 5RL and Pseudomonas putida TVA8 was higher on nanophase than conventional titania. Importantly, in terms of metabolism, bacteria attached to the nanophase surfaces had higher bioluminescence rates than on the conventional surfaces under all nutrient conditions. Thus, the results from this study show greater select bacterial metabolism on nanometer than conventional topographies, critical results with strong consequences for the design of improved biosensors for bacteria detection.
\end{abstract}

Keywords: bacteria, attachment, nanophase, topography, metabolism

\section{Introduction}

New synthetic nanomaterials have been designed and produced for applications in manufacturing and medicine. Nanomaterials refer to those with constituent dimensions less than $100 \mathrm{~nm}$ in at least one direction. Biomedical applications are numerous, particularly since mammalian tissue-forming cells have a measurable positive response to nanophase materials. It is not apparent whether these differences are due to surface chemistry or topography (Jeyachandran et al 2006; Zhao et al 2007), although some studies have indicated a stronger influence of nanotopography over chemistry on mammalian tissue-forming cell function (Miller et al 2002). Similarly, research has shown altered attachment rates for select bacteria on nanophase surfaces, although changes in metabolic responses have not been clearly defined. For example, while Staphylcoccus epidermis colonization decreased on nanophase compared to conventional titania (thus, showing promise for the creation of anti-infection orthopedic implants) Pseudomonas fluorescens 5RL colonization increased (Webster et al 2005; Colon et al 2007).

Nanophase materials have higher surface areas, surface defects, increased surface electron delocalization and greater numbers of surface grain boundaries. Since there is a higher percentage of atoms at their surfaces compared to conventional materials, surface properties are altered in nanophase materials and this results in higher surface reactivity to influence cellular responses (Barringer and Bowen 1982; Nieman et al 1991; Siegel and Fougere 1995a, 1995b; Siegel 1996; Wu et al 1996).

Applications involving mammalian tissue-forming cells have successfully utilized these unique surface properties of nanophase ceramics (Ahn and Ying 2000). For example, when compared to conventional alumina, titania, and hydroxyapatite (HA), osteoblast (bone-forming cell) adhesion was greater on nanophase alumina with either nanospherical or nanofiber grain sizes (Webster et al 2000b). Atomic force microscopy determined greater root-mean square surface roughness values 
for nanophase alumina (20 nm) compared to conventional alumina (17 nm) and titania (32 nm nanophase compared to $16 \mathrm{~nm}$ conventional).

Although the surface area for nanophase ceramics is greater than conventional ceramics, after results demonstrating increased functions of osteoblasts were normalized to this increased surface area (Webster et al 2001, 2002), it was apparent that the additional surface area was not the only reason for the observed increased cell adhesion. Of further note is that a variety of mammalian tissue-forming cells (such as chondrocytes [Kay et al 2003], bladder smooth muscle cells [Thapa et al 2003], fibroblasts [Webster et al 2000a], astrocytes [Turner et al 2000] and vascular smooth muscle cells [Miller et al 2002]) responded differently to nanostructured topographies. Furthermore, enhanced responses of mammalian tissue-forming cells have also been shown on nanostructured metals, ceramics, polymers, and composites thereof(Miller et al 2002; Kay et al 2003; Thapa et al 2003).

The attachment processes of mammalian and bacterial cells to surfaces are similar. Surface adhesion is preceded instantaneously by the formation of an organic molecular monolayer, consisting of proteins, polysaccharides, and/or glycoproteins (Abarzua and Jakubowski 1995; Cucarella et al 2002; Tang et al 2006). These adsorbed organic molecules may serve as a nutrient source for the attached bacteria and/or may change the surface chemistry (electrokinetic potential or surface tension) to enhance bacterial adhesion (Dexter et al 1975; Defrise and Gekas 1988; Elbert and Hubbell 1996).

Bacterial adhesion is, thus, affected by surface properties (Litzler et al 2007; Schildhauer et al 2007) such as hydrophobicity (Schackenraad et al 1992; Bos et al 2000; Karakeçili and Gümüşderelioglu 2002), hydrophilicity (Kiss et al 1996; Gomez-Suarez et al 2002), steric hindrance (Kuhl et al 1994; Rijnaarts et al 1999), and surface roughness (Medilanski et al 2002; Whitehead et al 2006). There is a positive correlation between protein adsorption and short-term bacterial attachment with surface property changes (Cunliffe et al 2003). Also, the strength of bacterial attachment has been positively correlated to surface topography (Boyd et al 2002). Detachment of bacteria is affected by surface properties (Powell and Slater 1982) and bacteria are most readily removed from the smoothest, most hydrophilic, neutral surfaces (Pasmore et al 2002).

However, limited research has been conducted on the relationship between bacterial attachment and nanophase materials (Curtis and Wilkinson 2001). The area of attachment for Pseudomonas sp. was shown to be inversely proportional to the average grain size of stainless steel (Sreekumari et al 2001). Webster and colleagues (2005) concluded that nanophase alumina and associated cast polymer surfaces had significantly higher bacterial (Pseudomonas fluorescens) adhesion than conventional surfaces of the same material. Pseudomonas fluorescens morphology, length, orientation, and flagellation differed between bacteria attached on ordered nano- or microstructures and randomly ordered surfaces (Diaz et al 2007). Although there is evidence that bacterial attachment is altered on nanophase surfaces, the mechanism behind this phenomenon as well as bacterial metabolism differences remain unclear. The objective of this in vitro study was to determine if bacterial metabolism is different on nanotopographies compared to conventional topographies, using titania as an example.

\section{Materials and methods Nanophase surfaces}

Forty percent rutile-/60\% anatase-phase nanospherical titania particles (Nanophase Technologies, Romeoville, IL) were compacted serially in a steel-tool die with a uniaxial pressing cycle $(0.2 \mathrm{GPa}$ to $0.8 \mathrm{GPa}$ over an eight-minute period at room temperature). The compacts were then sintered (in air at $10^{\circ} \mathrm{C} /$ minute for 120 minutes) to obtain a variety of grain sizes. Nanospherical grain size titania was sintered at $600^{\circ} \mathrm{C}$ and conventional grain size titania at $1200^{\circ} \mathrm{C}$. To facilitate adhesion testing, each $11 \mathrm{~mm}$ diameter compact was attached to the center of a glass slide with silicon-based sealant. The topography of the resulting compacts was quantified by atomic force microscopy (using an Autoprobe CP Atomic Force Microscope). Image analysis software (Pro-scan version $1.5 \mathrm{~b}$ ) was used to generate micrographs and to quantitatively compare surface roughness of the materials of interest in the present study. Titania grain size was calculated by averaging multiple-point Brunauer, Emmett, and Teller (BET) measurements. The phases of the nanophase and conventional titania were determined by X-ray diffraction using a Philips type PW2273/ 20 diffractometer. Diffraction signal intensity throughout the scan was monitored and processed using DMS software (Scintag Inc., Sunnyvale, CA). Measurements were run in triplicate per substrate type. The compacts were sterilized by autoclaving before the experiments.

\section{Bacterial culture}

Two bacterial cell lines were used in this experiment. The first was Pseudomnas fluorescens 5RL, a bioluminescent reporter induced by salicylate and naphthalene (King et al 1990). 
P. fluorescens $5 R L$ was initially cultured in $100 \mathrm{~mL}$ of luria broth (LB) media with $100 \mu \mathrm{L}$ of sodium salycilate for inducing luminescence and $100 \mu \mathrm{L}(14 \mathrm{mg} / \mathrm{L})$ of tetracycline. The cultures were incubated at room temperature $\left(22 \pm 1^{\circ} \mathrm{C}\right)$ with continuous shaking at $150 \mathrm{rpm}$. Cultures were harvested when the optical density at $600 \mathrm{~nm}$ was approximately 1.0. The optical density was determined using a Perkin Elmer Lambda 20 Spectrophotometer (Perkin Elmer Inc., Waltham, MA). The bacteria were harvested by four consecutive stages of centrifugation ( $6000 \mathrm{~g}$ for $10 \mathrm{~min}$ at $4{ }^{\circ} \mathrm{C}$ ) and re-suspended in phosphate-buffer solution (PBS) $(\mathrm{pH} 7.4$, $137 \mathrm{mM} \mathrm{NaCl}, 2.7 \mathrm{mM} \mathrm{KCl}, 8 \mathrm{mM} \mathrm{Na}_{2} \mathrm{HPO}_{4}$, and $2 \mathrm{mM}$ $\mathrm{KH}_{2} \mathrm{PO}_{4}$ ). The centrifugation step was necessary to remove the growth substrate from the solution to eliminate bacterial growth during the adhesion period. The PBS-buffered suspensions were allowed to equilibrate to room temperature before adhesion tests.

In addition to $P$. fluorescens 5RL, Pseudomonas putida TVA8 (also bioluminescent) was used in this study (Applegate et al 1998). These cultures were prepared from a frozen stock of $P$. putida TVA8, which was previously grown using toluene. One milliliter of the stock solution was added to $100 \mathrm{ml}$ of the mineral salt medium, followed by the addition of $1 \mathrm{~mL}$ of ethyl alcohol as a growth substrate and trichloroethylene to induce bioluminescence (Shingleton et al 1998). The flask was placed in a constant temperature room and shaken at $200 \mathrm{rpm}$. The culture was grown overnight to an optical density of 1.0 at $600 \mathrm{~nm}$ at room temperature.

Both cultures were diluted with PBS to a concentration of $1 \times 10^{8}$ cells/L to create suspensions prior to adhesion experiments. Bioluminescence for both suspended cultures was measured with a Zylux luminometer (Zylux Corporation, Oak Ridge, TN). To quantify the light produced by the attached bacteria, all slides and compacts were placed in a light tight chamber to measure bioluminescence using a Hamamastu Photomultiplier tube (Hamamastu Photonics, Bridgewater, NJ).

\section{Direct bacterial enumeration}

After luminescent measurements, slides were placed in a PBS-buffered fixative for 15 minutes. The slides and compacts were then rinsed gently with PBS and air-dried. One hundred microliters of DAPI (4'6-diamidino-2-phenylindole) at a concentration of $10 \mathrm{mg} / \mathrm{L}$ was applied to each coupon and the slide was incubated in the dark for 5 minutes (Yu et al 1995). Excess DAPI was rinsed from the slide, the coupons were allowed to air-dry, and then covered with a glass cover slip. Bacterial cell counts were conducted with a Nikon E 800 Bio-Research Microscope (Nikon Instrument, Inc., Melville, NY) at 1000x magnification. The UV filter cube was used to select the excitation wavelength range for optimal excitation. Fifteen fields of $0.914 \mathrm{~mm}^{2}$ for each sample were randomly selected for enumeration to ensure statistical significance. Cell counting completed automatically using image 1 software, Image Processing Tool Kit (Reindeer Graphics, Inc., Ashville, NC).

\section{Bioluminescent interference}

To evaluate the potential contribution of phosphorescence for the materials used in this study, light emission was monitored with and without bioluminescent bacteria. Titania was found to be somewhat luminescent, most likely due to background phosphorescence. To further evaluate this phenomenon, luminescent decay for sterile test compacts was evaluated for one hour. After evaluation of the results, the phosphorescence was determined to contribute only a minimal luminescence.

\section{Experimental system design}

An experimental system was constructed to evaluate continuous bacterial attachment onto nanophase and conventional materials. A chamber was designed to hold the glass slide with the attached compact and allow for continuous flow of liquid over the target surface. The flow rate was $1 \mathrm{ml} /$ minute using peristaltic pumps. In the adhesion stage of the experiment, approximately $1 \times 10^{8}$ cells $/ \mathrm{mL}$ of $P$. fluorescens 5RL or P. putida TVA8 in phosphate buffer solution flowed over titania compacts for 30 minutes. Adhesion under two conditions was assessed for both bacterial strains. In the first, phosphate buffer flowed through the system immediately after the adhesion stage for 30 minutes. In the second, a glucose solution flowed through the system for 30 minutes immediately following the adhesion period. A third assessment was conducted with P. putida TVA8. The adhesion period was 30 minutes as previously described. After adhesion, a mineral salt media with $1 \mathrm{ml} / \mathrm{L}$ of ethanol and $0.5 \mathrm{ml} / \mathrm{L}$ of tricholorethylene flowed over the compacts for an additional 30 minutes. All studies were conducted in parallel with three replicates.

\section{Results and discussion}

Material characterization studies provided evidence that nanophase titania was considerably more rough at the nanoscale than conventional titania (specifically, AFM root-mean-square roughness values were $32 \mathrm{~nm}$ and $16 \mathrm{~nm}$ for nanophase and conventional titania, respectively) (Figure 1). 


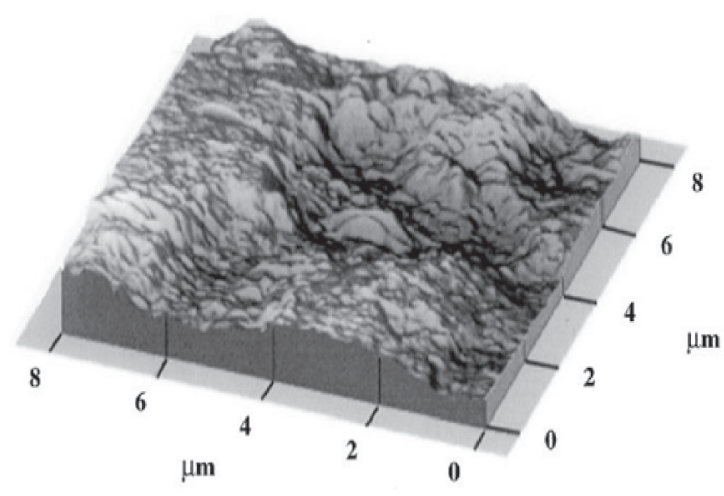

a) $32 \mathrm{~nm}$ grain size nanophase titania

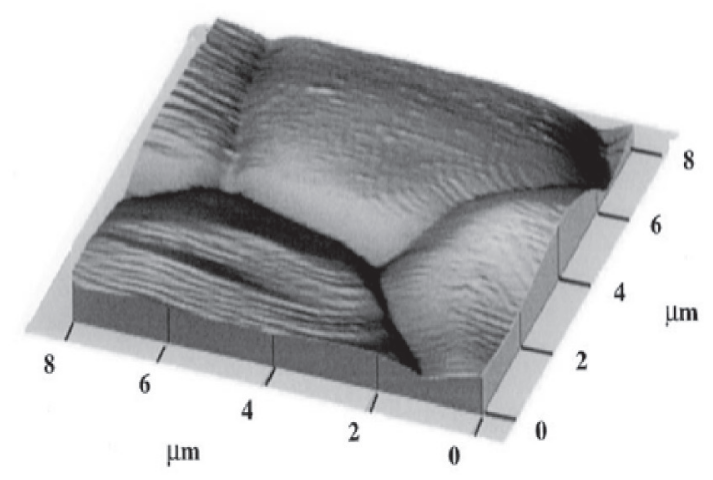

b) $2.12 \mu \mathrm{m}$ grain size conventional titania

Figure I Atomic force microscopy (AFM) micrographs of nanophase and conventional titania. AFM data provided evidence that nanophase titania was considerably more rough at the nanoscale than conventional titania (specifically, AFM root-mean-square roughness values were $32 \mathrm{~nm}$ and $16 \mathrm{~nm}$ for nanophase and conventional titania, respectively).

BET measurements also provided evidence that the average grain size for the nanoscale and conventional titania were $32 \mathrm{~nm}$ and $2.12 \mu \mathrm{m}$, respectively. X-ray diffraction spectra showed that the material phases did not change when titania was sintered at $600^{\circ}$ compared to $1200{ }^{\circ} \mathrm{C}(40 \%$ rutile and $60 \%$ anatase) (Figure 2).

The attachment of $P$. fluorescens 5RL and P. putida TVA8 was assessed on surfaces with differing topographies and nutrient conditions. $P$. fluorescens had a higher level of attachment and light emission on the nanophase material when compared to the conventional surface (Figure 3). No spatial differences in bacteria attachment were observed on the substrates. The presence of glucose in the post-attachment solution resulted in a small increase of microbial numbers on the surface and a higher emission of light for the conventional surface. On the nanophase surface, the solution containing glucose also enhanced bacterial numbers and light emission, although to a larger degree than on the conventional surface.
P. putida TVA8 attachment was similarly affected by both topography of the surface and solution nutrient conditions. Cell density on the nanophase surface was higher than the conventional surface under all three nutrient conditions (Figure 4). The light emission was higher for the conventional surface with the glucose solution. For the nanophase surface, light emission was similar for glucose and ethanol+trichloroethane $(\mathrm{EtOH}+\mathrm{TCE})$ solutions, but both were higher than the phosphate buffer solution.

Comparing P. fluorescens and P. putida, the number of attached bacteria per area was similar. The light emission for $P$. putida was slightly higher than that for P. fluorescens. The effect of the limited nutrient conditions resulted in lower bacterial numbers on each surface. Recent research has indicated that starvation conditions induce bacteria to adhere to the surfaces of stainless steel (Myszka et al 2006). However, the effect of low nutrient conditions on cell detachment was not assessed in this previous study.

Results shown in Tables 1 and 2 indicate that the activity or light emission of the attached bacteria was higher for the nanophase surface when compared to the conventional surface. This result is important given the interest in imbedding antimicrobial agents into biomaterials. Popat and colleagues (2007) reported that the adhesion of

Table I Ratio of bioluminescence to bacterial numbers for Pseudomonas fluorescens $5 R L$ attached to titania. All data are significantly different $(p<0.01)$ comparing respective conditions of nanophase to conventional titania

\begin{tabular}{ll}
\hline Titania formulation & Photons $/ \mathbf{s e c} / \mathbf{c e l l s} / \mathbf{c m}^{2}$ \\
\hline Conventional with phosphate buffer & 0.074 \\
Conventional with glucose & 0.081 \\
Nanophase with phosphate buffer & 0.091 \\
Nanophase with glucose & 0.099 \\
\hline
\end{tabular}

Table 2 Ratio of bioluminescence to bacterial numbers for Pseudomonas putida TVA8 attached to titania. All data are significantly different $(p<0.01)$ comparing respective conditions of nanophase to conventional titania

\begin{tabular}{ll}
\hline Titania formulation & Photons $/ \mathbf{s e c} / \mathbf{c e l l s} / \mathbf{c m}^{2}$ \\
\hline Conventional with phosphate buffer & 0.086 \\
Conventional with glucose & 0.095 \\
Conventional with EtOH + TCE & 0.088 \\
Nanophase with phosphate buffer & 0.097 \\
Nanophase with glucose & 0.10 \\
Nanophase with EtOH + TCE & 0.11 \\
\hline
\end{tabular}

Abbreviations: $\mathrm{EtOH}$, ethanol;TCE, trichloroethane. 


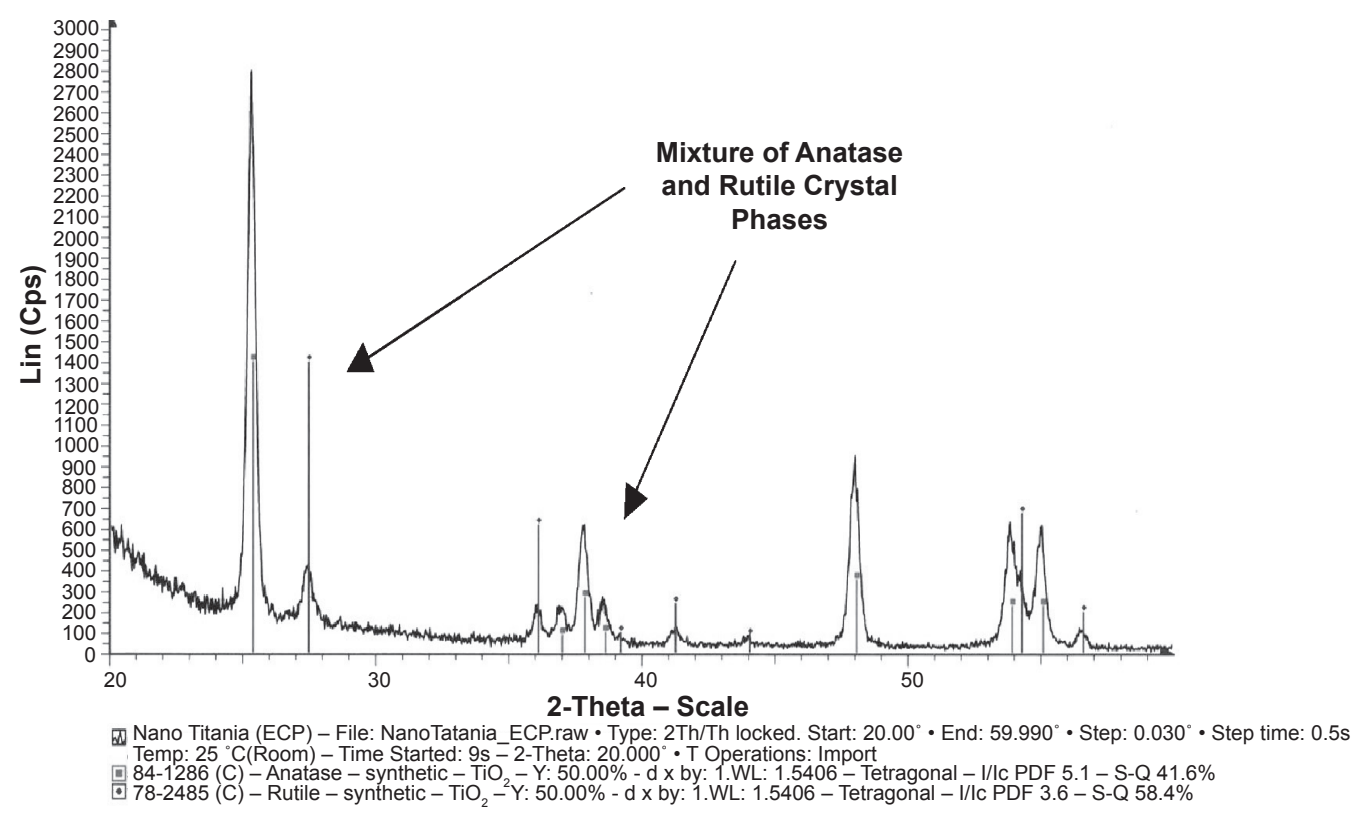

Figure 2 XRD spectra of nanophase and conventional titania illustrating a mixture of anatase and rutile crystal phases. Similar crystal phases were observed for both nanophase and conventional titania, thus, as an example, nanophase titania is only shown here.

Abbreviation: XRD, X-ray diffraction.

a)

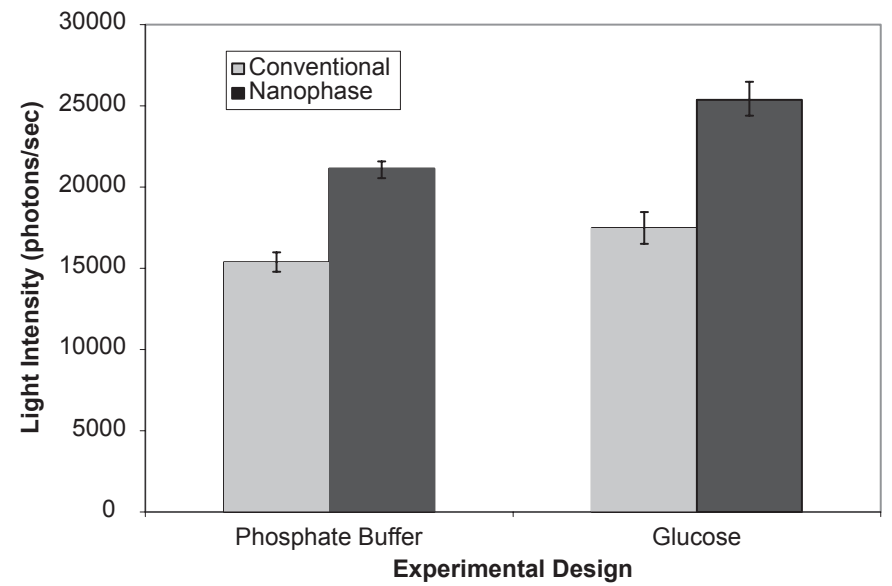

b)

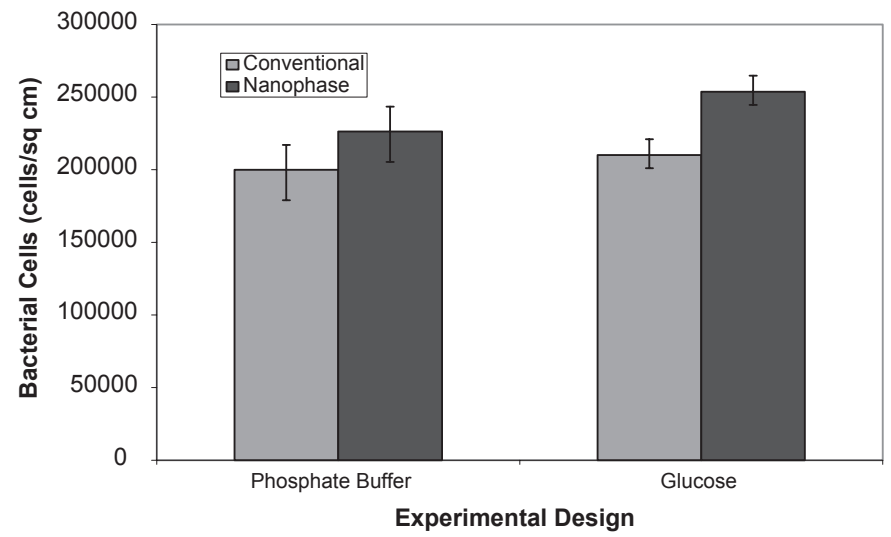

Figure 3 Light emission (a) and number (b) of attached bioluminescent bacteria Pseudomonas fluorescens $5 R L$ on titania as affected by the presence of a carbon source in the solution phase. Background luminesence was 960 photons/sec. All data are significantly different $(\mathrm{p}<0.01)$ comparing respective conditions of nanophase to conventional titania. 
a)

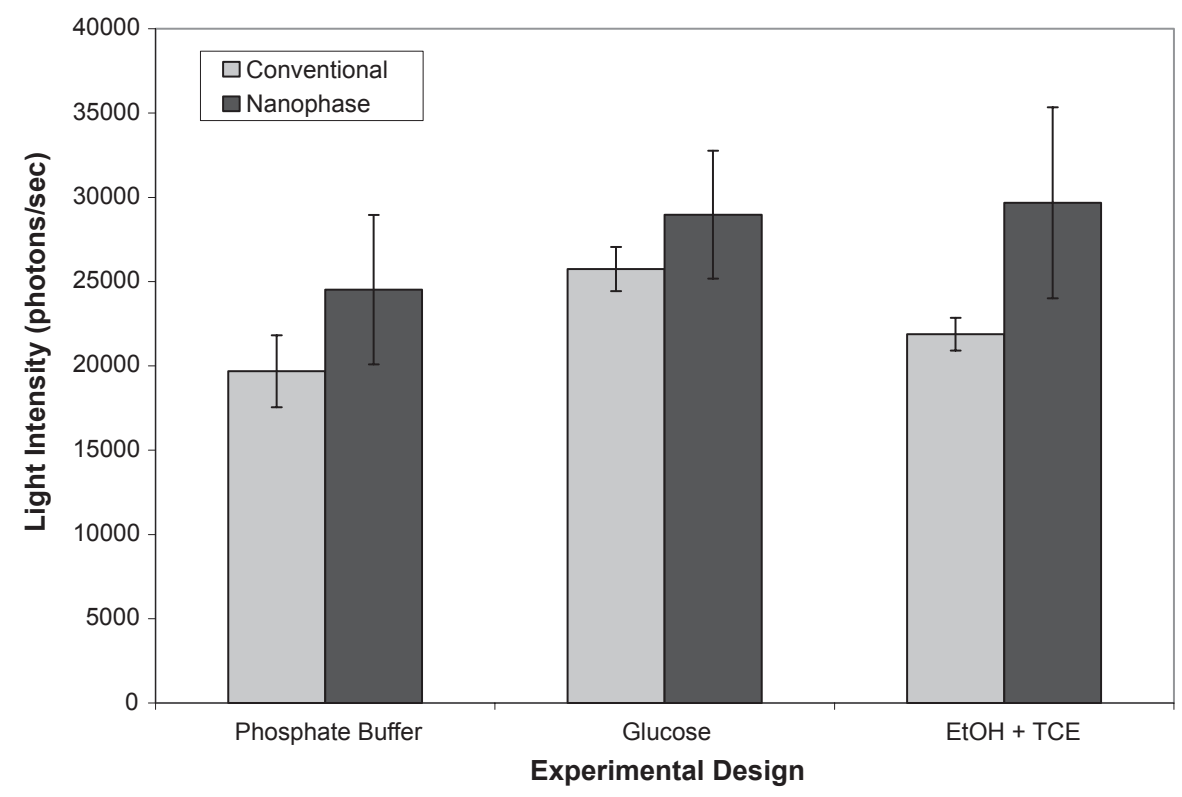

b)

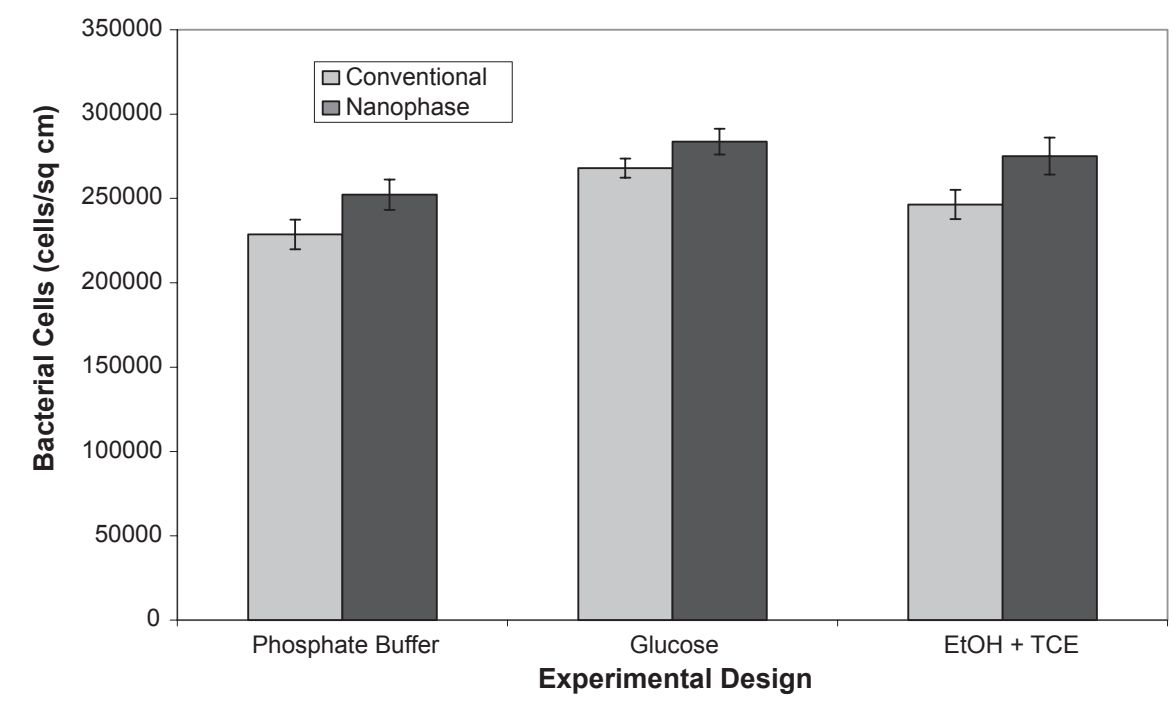

Figure 4 Light emission (a) and number (b) of attached bioluminescent bacteria Pseudomonas putida TVA8 on titania as affected by the presence of a carbon source in the solution. Background luminesence was 960 photons/sec. All data are significantly different $(p<0.01)$ comparing respective conditions of nanophase to conventional titania.

Staphylococcus epidermis was significantly reduced on titania nanotublar arrays loaded with gentamicin. Other research indicates that $S$. epidermis adhesion was lower on nanophase titania and nanophase $\mathrm{ZnO}$ (antimicrobial agent) when compared to respective conventional surfaces (Colon et al 2007). If metabolism is indeed enhanced on nanophase surfaces, then the impact of antimicrobial agents on biofilm development may be affected on such surfaces. For example, a higher activity rate may result in a more susceptible population of microorganisms for disinfection. Further research on this topic is needed to identify the exact relationship between enhanced disinfection and activity of attached microorganisms on nanophase surfaces.

\section{Conclusions}

Results from this study indicate that the adhesion of Pseudomonas fluorescens 5RL and Pseudomonas putida TVA8 was higher on nanophase titania when compared to conventional 
titania. Bacterial cells attached to the nanophase surface had a higher bioluminescence rate per cell than on the conventional surface. The presence of a carbon source in the post-attachment solution resulted in higher bacterial numbers and bioluminescence when compared to a phosphate buffer solution. Pseudomonas putida had a slightly lower level of bioluminesence than Pseudomonas fluorescens for both surfaces. Such results imply greater bacterial metabolism on nanotopographies compared to conventional topographies; results which can impact numerous fields from biosensors to implants.

\section{Acknowledgments}

The authors would like to thank the Whitaker Foundation for funding.

\section{References}

Abarzua S, Jakubowski S. 1995. Biotechnological investigation for the prevention of biofouling. In: Biological and Biochemical Principals for the Prevention of Biofouling. Mar Ecol Prog Ser, 123:301-11.

Ahn ES, Ying JY. 2000. Synthesis, sintering, and microstructure of nanocrystalline hydroxyapatite. Proc Mat Res Soc, 152:611-23.

Applegate BM, Kehrmeyer SR, Sayler GS. 1998. A chromosomally based tod-luxCDABE whole-cell reporter for benzene, toluene, ethybenzene, and xylene (BTEX) sensing. Appl Environ Microbiol, 64:2730-39.

Barringer EA, Bowen HK. 1982. Formation, packing, and sintering of monodispersed $\mathrm{TiO}_{2}$ powders. Comm Am Ceram Soc, 12:C199-202.

Bos R, Van der Mei HC, Gold J, et al. 2000. Retention of bacteria on a substratum surface with micro-patterned hydrophobicity. FEMS Microbiol Lett, 189:311-6.

Boyd RD, Verran J, Jones MV, et al. 2002. Use of atomic force microscope to determine the effect of substratum surface topography on bacterial adhesion. Langmuir, 18:2343-50.

Colon G, Ward BC, Webster TJ. 2006. Increased osteoblast and decreased Staphylococcus epidermidis functions on nanophase $\mathrm{ZnO}$ and $\mathrm{TiO}_{2}$.J Biomed Mater, 78A:595-603.

Cucarella C, Tormo MA, Knecht E, et al. 2002. Expression of biofilmassociated protein interfaces with host protein receptors of Staphylococcus aureus and alters the infective process. Infect Immun, 70:3180-8.

Cunliffe D, Alarcon CD, Peters V, et al. 2003. Thermoresponsive surface-grafted poly(N-isopropylacrylamide) co-polymers: Effect of phase transitions on protein and bacterial attachment. Langmuir, 19:2888-99.

Curtis A, Wilkinson A. 2001. Nanotechniques and approaches in biotechnology. Trends Biotechnol, 19:97-105.

Defrise D, Gekas V. 1988. Microfiltration membranes and the problem of microbial adhesion. Proc Biochem, 79:105-15.

Dexter SC, Sullivan JD, Williams J, et al. 1975. Influence of substrate wettability on the attachment of marine bacteria to various surfaces. Appl Environ Microbiol, 30:298-310.

Diaz C, Schilardi PL, Salvarezza RC, et al. 2007. Nano/Microscale order affects the early stages of biofilm formation on metal surfaces. Langmuir, 23:11206-12.

Elbert DL, Hubbell JA. 1966. Surface treatments of polymers for biocompatibility. Ann Rev Mater Sci, 26:365-73.

Gomez-Suarez C, Pasma J, Van der Borden AJ, et al. 2002. Influence of extracellular polymeric substances on deposition and redeposition of Pseudomonas aeruginosa to surfaces. Microbiology, 148:1161-6.

Jeyachandran YL, Narayandass SK, Mangalarij D, et al. 2006. The effect of surface composition of titanium films on bacterial adhesion. Biomed Mater, 1:L1-L9.
Karakeçili AG, Gümüşderelioglu M. 2002. Comparison of bacterial and tissue cell adhesion on hydrophilic/hydrophobic biomaterials. J Biomater Sci Polym Ed, 13:185-95.

Kay S, Thapa A, Haberstroh KM, et al. 2002. Nanostructured polymer: Nanophase ceramic composites enhance osteoblast and chondrocyte adhesion. Tissue Eng, 8:753-9.

King JMH, DiGrazia PM, Applegate BM, et al. 1990. Rapid, sensitive bioluminescent reporter technology for naphthalene exposure and biodegradation. Science, 249:778-81.

Kiss E, Samu J, Toth A, et al. 1996. Novel ways of covalent attachment to poly(ethyleneoxide) onto polythene: Surface modification and characterization by XPS and contact angle measurements, Langmuir, 12:1651-66.

Kuhl T, Leckband E, Lasic D, et al. 1994. Modulation of interaction forces between bilayers exposing short-chained ethylene oxide headgroups. Biophys J, 66:1479-89.

Litzler PY, Benard L, Barbier-Frebourg N, et al. 2007. Biofilm formation on pyrolytic carbon heart valves: Influene of surface free energy, roughness, and bacterial species. J Thorac Cardio Surg, 134:1025-30.

Medilanski E, Kaufmann K, Wick L, et al. 2002. Influence of the surface topography of stainless steel on bacterial adhesion. Biofouling, 18:193-9.

Miller DM, Thapa A, Haberstroh KM, et al. 2002. An in-vitro study of nano-fiber polymers for guided vascular regeneration. Mater Res Soc Symp Proc, 711:GG3.2.1-GG3.2.9.

Myszka K, Czaczyk K, Schmidt MT, et al. 2007. Cell surface properties as factors involved in Proteus vulgaris adhension to stainless steel under starvation conditions. World J Microb Biotechnol, 23:1605-16.

Nieman GW, Weertman JR, Siegel RW. In: Van Aken DC (ed). Microcomposites and Nanophase Materials. Warrendale, PA: TMS, 1991.

Pasmore M, Todd P, Pfiefer B, et al. 2002. Effect of polymer surface properties on the reversibility of attachment of Pseudomonas aeruginosa in the early stages of biofilm development. Biofouling, 18:65-77.

Powell MS, Slater NK. 1982. Removal rates of bacterial cells from glass surfaces by fluid shear. Biotechnol Bioeng, 21:2523-32.

Rijnaarts HM, Norde W, Lyklema J, et al. 1999. DLVO and steric contributions to bacteria deposition in media of different ionic strengths. Coll Surf B-Biointerf, 14:179-87.

Schackenraad J, Stokroos I, Bartels H, et al. 1992. Patency of small calibre, superhydrophobic, E-PTFE vascular grafts: A pilot study in rabbit carotid artery. Cells Mater, 2:193-9.

Schildhauer TA, Robie B, Muhr G, et al. 2006. Bacterial adherence to tantalum versus commonly used orthopedic metallic implant materials. J Orthop Trauma, 20:476-83.

Shingleton JT, Applegate BM, Nagel AC, et al. 1998. Induction of the tod operon by trichloroethylene in Pseudomonas putida TVA8. Appl Environ Microbiol, 64:5049-52.

Siegel RW. 1996. Creating nanophase materials. Sci Am, 275:42-9.

Siegel RW, Fougere GE. 1995a. Mechanical properties of nanophase metals. Nanostruct Mater, 6:205-15.

Siegel RW, Fougere GE. 1995b. Grain size dependent mechanical properties on nanophase materials. Mater Res Soc Symp Proc, 362:219-23.

Sreekumari KR, Nandakumar K, Kikuchi Y. 2001. Bacterial attachment to stainless steel welds: Significance of substratum microstructure. Biofouling, 17:303-13.

Tang HY, Wang AF, Liang XM, et al. 2006. Effect of surface proteins on Staphylococcus epidermidis adhesion and colonization on silicone. Coll Surf Biointerf, 51:16-25.

Thapa A, Webster TJ, Haberstroh KM. 2003. Polymers with nano-dimensional surface features enhance bladder smooth muscle cell adhesion. J Biomed Mater Res, 67A:1374-81.

Webster TJ, Ergun C, Doremus RH, et al. 2000a. Specific proteins mediate enhanced osteoblast adhesion on nanophase ceramics. J Biomed Mater Res, 51:475-87.

Webster TJ, Siegel RW, Bizios R. 2000b. Enhanced functions of osteoblasts on nanophase ceramics. Biomaterials, 21:1803-10. 
Webster TJ, Schadler LS, Siegel RW, et al. 2001. Mechanisms of enhanced osteoblast adhesion on nanophase alumina involve vitronectin. Tissue Eng, 7:291-9.

Webster TJ, Tong Z, Liu J, et al. 2005. Adhesion of Pseudomonas fluorescens on nanophase materials. Nanotechnology, 16:S449-63.

Whitehead KA, Rogers D, Colligon J, et al. 2006. Use of the atomic force microscope to determine the effect of substratum topography on the ease of bacterial removal. Coll Surf Biointerf, 51:44-54.
Wu SJ, DeJong LC, Rahaman MN. 1996. Sintering of nanophase $\mathrm{Al}_{2} \mathrm{O}_{3}$ powder. J Am Ceram Soc, 79:2207-11.

Yu W, Dodds WK, Banks MK, et al. 1995. Optimal staining and sample storage times for direct microscopic enumeration of total and active bacteria in soil using two fluorescent dyes. Appl Environ Microbiol, 61:3367-78.

Zhao Q, Liu Y, Wang C, et al. 2007. Bacterial adhesion on ion-implanted stainless steel surfaces. Appl Surf Sci, 253:8674-80. 